\title{
Birth Head Circumference
}

National Cancer Institute

\section{Source}

National Cancer Institute. Birth Head Circumference. NCI Thesaurus. Code C101221.

The measurement around a neonate's head at birth. 